\title{
Bank Crisis: The Current Scenario of Merger and Acquisition in India
}

\author{
Smriti Nagaria, R. Lavanya Kumari
}

\begin{abstract}
Banks are the pillars that support the financial structure of a modern economic system. Their successes and screw ups are inextricably connected to the Indian economy. Indian banks have additionally had their proportion of troubles with consequences for the country. Bank runs, awful debt, etc, are a number of the persistent issues confronted with the aid of banking structures globally. The study focus on how the banking crisis impact on the economy. These days, the banking system in India has been beset through a big terrible debt crisis, which is crimping credit score to the productive sectors of our economy. This weakening in financial institution credit score has dampening impact on domestic funding, leading to subdued increase in employment and Gross domestic Product. Regulatory interventions and oversight of central banks, government aid and stakeholder involvement arise widely a success in preserving stability, even though punctuated with obtrusive disasters. However, it may be the best time to reconsider the primary design of the banking device and restructure it by addressing the flaws in its present day shape through mergers and acquisitions. Furthermore the paper concludes that merger is a helpful strategy through this bank can expand their operations and the overall growth.
\end{abstract}

Keywords: Amalgamations, Banks, Indian economy and Mergers .

\section{INTRODUCTION}

In the present scenario, the Banking System in India has been beset through a huge awful debt crisis, which is crimping credit score to the effective sectors of our economy. This weakening in bank credit score has dampening effect on domestic funding, main to subdued growth in employment and Gross domestic Product. Consequently, it is able to be the correct time to rethink the primary design of the banking machine and restructure it by using addressing the failings in its modern shape. In very large phrases, traditional banks have 3 middle features performing as economic 'investment' automobile for savers through accepting deposits, as credit deliver car for businesses by lending (inclusive of bill discounting and provision of running capital), and imparting liquidity to facilitate transactions in economic system by using putting in a charge gadget.

Manuscript published on January 30, 2020.

* Correspondence Author

Ms.Smriti Nagaria*, Assistant Professor in the Department of Business Management, St.Joseph's Degree \& PG College,Hyderabad

R.Lavanya Kumari, lecturer in Loyola Academy ,Old Alwal, Telangana.

(C) The Authors. Published by Blue Eyes Intelligence Engineering and Sciences Publication (BEIESP). This is an open access article under the CC-BY-NC-ND

license (http://creativecommons.org/licenses/by-nc-nd/4.0/)
Traditional banks have combined those three functions as included behemoths. Further, balance sheets of Indian banks are frequently deeply intertwined because of extensive crossholding in their financial gadgets. Consequently, any condition is essential for bank reasons panic because of the opportunity of expansion which is additionally affects adversely to other banks. Hence forth it would possibly lead to a complete-blown economic crisis, inflicting a horrible credit score squeeze for the economic system as an entire. This terrible expected power of government which will rescue a weak bank as it is a burden to the taxpayer. It additionally gives perverse incentives for bankers, as they know that their flanks are included with the aid of public cash. After the introduction of implicit or express deposit insurance sponsored with the aid of the government, financial institution runs have in most cases come to be a non-issue. Today, the genesis of most troubles of banks lies in bad debt associated with poor lending choices, adverse macroeconomic situations, flaws in legal machine, political elements, and so on.

\subsection{History of Crisis}

From the year 2004-05 to 2008-09 the credit score increased, during that period industrial solvency known as 'non-food credit' doubled. The global economy was in addition to the booming of Indian financial system. Companies of India lent extremely with the intention to benefit of the boom opportunities, huge amount invested into infrastructure and the type of sectors like telecommunication, electricity, roadways, aeronautics and metal. Businessmen had been triumph over with exuberance, logically and partially irrational. Fact is that, many others begin to be involved in a generation of $9 \%$ increase in India. Thereafter in the year 2016-17 many things went wrong. In the present scenario, the banking system of India has been beset through a huge awful debt crisis, which is crimping credit score to the effective sectors of our economy. This weakening in bank credit score has dampening effect on domestic funding, main to subdued growth in employment and Gross domestic Product. Consequently, it is able to be the correct time to rethink the primary design of the banking machine and restructure it by using addressing the failings in its modern shape.

1.2 The aim of the paper is carried out with two main objectives:

- To study the impact of crisis on the banking system

- To identify the reasons of mergers and acquisitions on selected banks 
Bank Crisis: The Current Scenario of Merger and Acquisition in India

\subsection{Research Methodology}

The paper is based on both primary and secondary data where primary data is collected from sources such as newspaper articles ,business magazines and secondary data from finance websites and RBI website.

\section{IMPACT OF BANKING CRISIS}

Indian Banks have experienced a worse year within the beyond decades than what it had encountered within the year that had simply exceeded by. After many false hopes during the last few years, there appears to be a brand new dawn for the banking industry in the year 2019 particularly ready for a protracted innings, despite the fact that there can be occasional bouncers either from the government in an election year to win votes, or a economic calamity from shorelines a ways away.

During the year 2017-18 the public sector institutions made Rs 85,400 crore losses, whilst private banks endured to be profitable. 6 of 21 public sector banks have seen the severest strain with $1 / 5^{\text {th }}$ of their mortgage portfolio turned to bad. 12 banks form losses in the $1 / 3$ quarter it is an improvement. The consecutive quarterly losses resolved their capital and desolate potential to lend. During the same year public sector institutions can't be recovered the share market quickly as the gap leaved by them became suddenly by non bank lenders.

Few of these banks won't be in best form, however they have got stable depositors base and geographical reach to their gain, despite the fact that technology is breaking such barriers. 4 of 12 banks below Prompt Corrective Action are probably to be released out of the regulatory sanction quickly aided through mortgage recoveries and government largesse in throwing taxpayer cash into them.

Financial frauds retain to resolve the economy of India. Despite the efforts of government toward fast detection and accountability, the variety of fraud cases reported during the year 2018-19 by using banks extended by way of $15 \%$ in comparison to the previous year. As per the latest report by Reserve bank of India (RBI), mentioned that the growth rate of frauds may be no longer sizeable but the amount worried in frauds has long increased up through a whopping 73.8\%. The below table shows the financial year 2018-2019, banking sector announced 6,801 frauds corresponding to an amount of Rs 71, 542.93 crore as compared with 5,916 cases related to Rs 41,167.04 crore introduced in 2017-18. In comparison to this, state-run banks pronounced the number of 3,766 of frauds amounting to Rs 64,509.43 crore while towards 2,885 cases related to Rs $38,260.8$ crore.
Table: 2.1 Bank Group-wise Fraud Cases

\begin{tabular}{c|c|c|c|c|}
\hline $\begin{array}{c}\text { Bank } \\
\text { Group }\end{array}$ & \multicolumn{2}{|c|}{$2017-2018$} & \multicolumn{2}{c|}{$2018-2019$} \\
\hline & $\begin{array}{c}\text { No. of } \\
\text { Frauds }\end{array}$ & $\begin{array}{c}\text { Amount } \\
\text { Involved } \\
\text { (million) }\end{array}$ & $\begin{array}{c}\text { No. of } \\
\text { Frauds }\end{array}$ & $\begin{array}{c}\text { Amount } \\
\text { Involved } \\
\text { (million) }\end{array}$ \\
\hline Public & 2885 & $382,608.7$ & 3,766 & $645,094.3$ \\
Sector & $(48.8)$ & $(92.9)$ & $(55.4)$ & $(90.2)$ \\
Banks & & & & \\
\hline Private & 1,975 & $24,782.5$ & 2,090 & $55,151.4$ \\
Sector & $(33.4)$ & $(6.0)$ & $(30.7)$ & $(7.7)$ \\
Banks & & & & \\
\hline Foreign & 974 & $2,560.9$ & 762 & $9,553.0$ \\
Banks & $(16.5)$ & $(0.6)$ & $(11.2)$ & $(1.3)$ \\
\hline Financial & 12 & $1,647.0$ & 28 & $5,534.1$ \\
Institutions & $(0.2)$ & $(0.4)$ & $(0.4)$ & $(0.8)$ \\
\hline Small & 65 & 61.9 & 115 & 75.2 \\
Finance & $(1.1)$ & $(0.0)$ & $(1.7)$ & $(0.0)$ \\
Banks & & & & \\
\hline Payment & 3 & 9 & 39 & 21.1 \\
Banks & $(0.1)$ & $(0.0)$ & $(0.6)$ & $(0.0)$ \\
\hline Local Area & 2 & 0.4 & 1 & 0.2 \\
Banks & $(0.0)$ & $(0.0)$ & $(0.0)$ & $(0.0)$ \\
\hline Total & $\mathbf{5 , 9 1 6}$ & $411,670.4$ & 6,801 & $715,429.3$ \\
$(100)$ & $(100)$ & $(100)$ & $(100)$ \\
\hline
\end{tabular}

Source: $w w w . r b i . o r g$

The majority of frauds stated in the year 2018-19 due to PSBs which constitute the biggest share market in bank lending. It becomes accompanied with the aid of privately owned banks and overseas banks. It became unexpected that foreign banks managed to dollar the fashion and recorded a lesser variety of fraud cases however the quantity concerned raised sharply. As per the last year, overseas banks recorded 974 cases of fraud and the quantity concerned turned into Rs 2,560.9 million. In the same year foreign banks recorded 762 instances the quantity concerned changed into Rs 9,553 million. In phrases of area wise operations, frauds associated with advances constituted the fundamental proportion of the amount sophisticated in frauds, whilst the portion of frauds in off-balance sheet items reduced a year ago. The table below indicates. 
Table: 2.2 Area of Operation (Fraud Cases)

\begin{tabular}{|c|c|c|c|c|}
\hline \multirow{2}{*}{$\begin{array}{l}\text { Area of } \\
\text { Operation }\end{array}$} & \multicolumn{2}{|c|}{$2017-2018$} & \multicolumn{2}{|c|}{ 2018-2019 } \\
\hline & $\begin{array}{l}\text { No. of } \\
\text { Frauds }\end{array}$ & $\begin{array}{l}\text { Amount } \\
\text { Involved } \\
\text { (million) }\end{array}$ & $\begin{array}{l}\text { No. of } \\
\text { Frauds }\end{array}$ & $\begin{array}{l}\text { Amount } \\
\text { Involved } \\
\text { (million) }\end{array}$ \\
\hline Advances & $\begin{array}{l}2525 \\
(42.7)\end{array}$ & $\begin{array}{c}225,583 . \\
2(54.8)\end{array}$ & $\begin{array}{l}3,606 \\
(53.0)\end{array}$ & $\begin{array}{c}645,481 . \\
7(90.2)\end{array}$ \\
\hline Off-Balance Sheet & $\begin{array}{c}20 \\
(0.3)\end{array}$ & $\begin{array}{c}162,876 \\
7(39.6)\end{array}$ & $\begin{array}{c}33 \\
(0.5)\end{array}$ & $\begin{array}{c}55,375.2 \\
(7.7)\end{array}$ \\
\hline $\begin{array}{l}\text { Foreign Exchange } \\
\text { Transactions }\end{array}$ & $9(0.2)$ & $\begin{array}{c}14,258.0 \\
(3.5)\end{array}$ & $\begin{array}{c}13 \\
(0.2)\end{array}$ & $\begin{array}{c}6953.8 \\
(1.0)\end{array}$ \\
\hline Card/Intemet & $\begin{array}{l}2,059 \\
(34.8)\end{array}$ & $\begin{array}{c}1,095.6 \\
(0.3)\end{array}$ & $\begin{array}{l}1,866 \\
(27.4)\end{array}$ & $\begin{array}{l}713.8 \\
(0.1)\end{array}$ \\
\hline Deposits & $\begin{array}{c}697 \\
(11.8)\end{array}$ & $\begin{array}{c}4,622.7 \\
(1.1)\end{array}$ & $\begin{array}{c}596 \\
(8.8)\end{array}$ & $\begin{array}{c}1,483.1 \\
(0.2)\end{array}$ \\
\hline $\begin{array}{c}\text { Inter-Branch } \\
\text { Accounts }\end{array}$ & $6(0.1)$ & $11.9(0.0)$ & $3(0.0)$ & $1.1(0.0)$ \\
\hline Cash & $\begin{array}{l}218 \\
(3.7)\end{array}$ & $\begin{array}{l}403.4 \\
(0.1)\end{array}$ & $\begin{array}{l}274 \\
(4.0)\end{array}$ & $\begin{array}{l}555.4 \\
(0.1)\end{array}$ \\
\hline $\begin{array}{c}\text { Cheques / Demand } \\
\text { Drafts etc }\end{array}$ & $\begin{array}{c}207 \\
(3.5) \\
\end{array}$ & $\begin{array}{c}341.2 \\
(0.1) \\
\end{array}$ & $\begin{array}{l}189 \\
(2.8) \\
\end{array}$ & $\begin{array}{c}336.6 \\
(0.0) \\
\end{array}$ \\
\hline $\begin{array}{l}\text { Clearing Accounts } \\
\text { etc. }\end{array}$ & $\begin{array}{c}37 \\
(0.6) \\
\end{array}$ & $56.2(0.0)$ & $\begin{array}{c}24 \\
(0.4) \\
\end{array}$ & $\begin{array}{c}2,088.1 \\
(0.3)\end{array}$ \\
\hline Others & $\begin{array}{l}138 \\
(2.3)\end{array}$ & $\begin{array}{c}2,421.5 \\
(0.6) \\
\end{array}$ & $\begin{array}{l}197 \\
(2.9)\end{array}$ & $\begin{array}{c}2,440.5 \\
(0.3)\end{array}$ \\
\hline Total & $\begin{array}{c}5,916 \\
(100.0) \\
\end{array}$ & $\begin{array}{c}411,670 . \\
4(100)\end{array}$ & $\begin{array}{l}6,801 \\
(100) \\
\end{array}$ & $\begin{array}{c}715,429 . \\
3(100)\end{array}$ \\
\hline
\end{tabular}

Source: $w w w . r b i . o r g$

The Non performing assets (NPA) formation has slowed extensively across the sector and recoveries from recent NPAs are streaming in as it is a mark in the year 2019 as a bounce-back year, industry's bad loans have been at over $10 \%$ of total as on March 2018, up from much less than $4 \%$ in 2014, it rose from round 7\% in fiscal 2016 and in the period up to September, it was at $10.8 \%$. Public Sector Banks are the major players of the financial system. But the performances of such banks were affected by huge amount of NPAs. The rise in the level of NPA was very steep since 2012 and size of NPA of PSBs had been very large from 2015 onwards. Such alarming figures of NPA can be associated with factors such as spillover effects of global recession, sluggish domestic economy, willful defaults and poor performance of the corporate borrowers.

Table: 2.3 Trends in Non Performing Assets \& Classification of Assets

\begin{tabular}{|c|c|}
\hline \multicolumn{2}{|l|}{ Gross NPAs } \\
\hline Closing balance for $2016-17$ & 7.918 \\
\hline Opening balance for $2017-18$ & 7.625 \\
\hline Addition during 2017-18 & 6.043 \\
\hline Recovered during 2017-18 & 1.283 \\
\hline Written ofr during 2017-18 & 1.627 \\
\hline Closing balance for $2017-18$ & 1.0397 \\
\hline $\begin{array}{l}\text { Gross NPAs } \\
\text { as \% Or Gross } \\
\text { Advances }\end{array}$ & \\
\hline
\end{tabular}

\begin{tabular}{|l|c|c|}
\hline & FY.17 & FY.18 \\
\hline Standard assets & 90.4 & 88.5 \\
\hline Sub-standard assets & 2.5 & 2.8 \\
\hline Doubtful assets & 6.7 & 8 \\
\hline Loss assets & 0.3 & 0.6 \\
\hline
\end{tabular}

Source: $w$ ww.rbi.org

By 2020 Better recoveries and drop in sparkling bad-debts are appropriately to decrease banks Non-Performing Assets (NPAs) almost nearly 8\%, NPA confines the banking system had unsound at $11.5 \%$ in 2018 and then declined to 9.3\% within the year 2019. Asset incredible of banks need to witness a decisive turnaround this fiscal (2020) with gross NPAs lowering by way of 350 basis points (bps) over two years and round $8 \%$ by March 2020. This can be driven through a combination of reduction in clean accretions to NPA further to stepped up recoveries from current NPA debts. The general (PSBs), that account over $80 \%$ of the NPAs system, ought to set their gross NPAs climb down over 400 basis points (bps) to close to $10.6 \%$ by way of March 2020 from a top of 14.6\% in March 2018.

\section{MERGERS AND ACQUISITIONS IN INDIA}

Mergers in India are essentially a bail-out exercise. However in contrast to the past, where failed non-public banks had been merged with public banks to keep depositors, the merger among these three (Bank of Baroda, Vijaya Bank and Dena Bank), albeit compelled, is consolidation of banks below the identical promoter to achieve economies of scale and to reduce of duplication. The achievement of this workout might approach the method for the new government to push greater mergers of banks. Due to the sudden decreased economic growth the (GoI) Government of India announced merging of banks deserved to recover it from the 6 year lowest level economy.

\section{Advantages of Mergers \& Acquisitions of Bank}

- It will assist the banks to scale up its commercial enterprise and benefit a huge variety of customers quick.

- It assist to fill the commercial enterprise gap, to authorize the business to as much as item or era space and being obtained with the aid of the large business firm to improve its era as a plan of action efficiently.

- To maintain effective performance ratio to the commercial enterprise and operations of banking.

- To reduce the ratio of risk factor with the aid of merging into one.

- It helps in enhancing of technology, increase in profit and raise the standard of living

\section{Disadvantages of Mergers \& Acquisitions of Bank}

- To compliance and chance consistencies each the merged banks have unique angle of thinking with distinctive risk culture so as it brings an adverse impact on the benefit of the corporation.

- A bad way of life as the financial institution best recall the angle of amalgamating on material not at all take into account their humans or way of life into account that is the purpose why many financial institution mergers in the end fail.

The amalgamating of 10 PSB's into 4 after the merging the country could have best 12 PSB's. The amalgamating for this anchor banks are the Punjab National Bank, Canara bank, Union Bank of India and the Indian Bank. In order to this, amalgamating banks such as Vijaya bank and Dena bank have been incorporated into Bank of Baroda (BoB) \& State Bank of India (SBI) broke into globally top 50 after merging with itself 5 of its partner banks. 
Bank Crisis: The Current Scenario of Merger and Acquisition in India

By the fourth quarter of the financial year, however, Punjab National Bank changed into left with almost Rs 140-billion fraud perpetrated. Moreover, yields on 10-year government securities additionally saw sharp swings, falling from $7.47 \%$ to $6.19 \%$ closing year and returned to $7.4 \%$ ranges now. The below table depicts the list of Amalgamating Banks.

Table: 3.1 List of Amalgamating Banks \& its Net worth

\begin{tabular}{|c|c|c|c|}
\hline $\begin{array}{l}\text { Anchor } \\
\text { bank }\end{array}$ & $\begin{array}{l}\text { Amalgamating } \\
\text { banks }\end{array}$ & $\begin{array}{l}\text { Net } \\
\text { wort } \\
\text { h } \\
\end{array}$ & $\begin{array}{l}\text { Bank size } \\
\text { after } \\
\text { amalgamation }\end{array}$ \\
\hline PNB & $\begin{array}{l}\text { Oriental Bank } \\
\text { of Commerce } \\
\& \& \\
\text { United Bank of } \\
\text { India }\end{array}$ & $\begin{array}{l}\text { Rs } \\
17.94 \\
\text { lakh } \\
\text { srore. }\end{array}$ & $\begin{array}{l}\text { Second largest } \\
\text { bank in India }\end{array}$ \\
\hline $\begin{array}{l}\text { Canara } \\
\text { Bank }\end{array}$ & Syndicate Bank & $\begin{array}{l}\text { Rs } \\
15.20 \\
\text { lakh } \\
\text { crore. }\end{array}$ & $\begin{array}{l}\text { Fourth largest } \\
\text { bank in India }\end{array}$ \\
\hline $\begin{array}{l}\text { Union } \\
\text { Bank of } \\
\text { India }\end{array}$ & $\begin{array}{l}\text { Andhra Bank \& } \\
\text { Corporation } \\
\text { Bank }\end{array}$ & $\begin{array}{l}\text { Rs } \\
14.59 \\
\text { lakh } \\
\text { srorel }\end{array}$ & $\begin{array}{l}\text { Fifth largest } \\
\text { bank in India }\end{array}$ \\
\hline $\begin{array}{l}\text { Indian } \\
\text { Bank }\end{array}$ & $\begin{array}{l}\text { Allahabad } \\
\text { Bank }\end{array}$ & $\begin{array}{l}\text { Rs } \\
8.08 \\
\text { lakh } \\
\text { crore. }\end{array}$ & $\begin{array}{l}\text { Seventh largest } \\
\text { bank in India }\end{array}$ \\
\hline $\begin{array}{l}\text { Bank of } \\
\text { Baroda }\end{array}$ & $\begin{array}{l}\text { Yijaya Bank \& } \\
\text { Dena Bank }\end{array}$ & $\begin{array}{l}\text { Rs } \\
16.13 \\
\text { lakh } \\
\text { srore } \\
\end{array}$ & $\begin{array}{l}\text { Third largest } \\
\text { bank in India }\end{array}$ \\
\hline IDFC & $\begin{array}{l}\text { Capital First } \\
\text { (IDFC First } \\
\text { Bank) }\end{array}$ & $\begin{array}{l}\text { Rs } \\
1.03 \\
\text { lakh } \\
\text { crore. }\end{array}$ & \\
\hline
\end{tabular}

\section{Source: https://affairscloud.com}

- The above table indicates that PNB (Punjab National Bank) Punjab National Bank, Oriental Bank of Commerce \& United Bank of India are the three banks formed as India's second-largest lender with a entity of combined total 18 lakh crore business, with India's second largest branch network with11, 437 branches.

- Canara Bank and Syndicate Bank are merged to set up one more big business that is the fourth biggest PSB, with an amount of Rs 15.2 lakh crore and 10,324 number of branches leaded as the third largest network in India.

- Union Bank of India amalgamated with Andhra Bank \& Corporation Bank which stood as the country's fifth largest PSB, with a business worth Rs 14.6 lakh crore, and also it has 9,609 branches which leaded as the fourth largest network.

- When Indian Bank merged with Allahabad Bank it leaded as the new entity of the seventh largest PSB, with Rs 8.08 lakh crore of business.

- IDFC first bank: Is the first capital as non-banking financial company (NBFC) which is totally amalgamated with IDFC bank in the month of December $18^{\text {th }} 2018$ to set up the banks as IDFC First Bank. It is merged on January $13^{\text {th }} 2018$ and also it has a debt asset book value of Rs 1.03 lakh crore, newly formed IDFC First bank.
Table 3.2 Mergers (2010-2017)

\begin{tabular}{|c|c|}
\hline Rank & Bank \\
\hline \hline 1 & State Bank of India \\
\hline \hline 2 & Punjab National Bank \\
\hline \hline 3 & Bank of Baroda \\
\hline \hline 5 & Canara Bank \\
\hline 6 & Union Bank of India \\
\hline 7 & Bank of India \\
\hline \hline 8 & Indian Bank \\
\hline \hline 9 & Central Bank of India \\
\hline \hline 10 & Indian Overseas Bank \\
\hline \hline 11 & UCO bank \\
\hline \hline 12 & Punk of Maharashtra \\
\hline & Source https://affairscloud com Sind Bank \\
\hline
\end{tabular}

Source: https://affairscloud.com

Presently, Public Sector Unit (PSU) banks of six which are remain independent without any merger with other banks. The below table shows the public sector unit banks which are remain independent in the year 2019.

Table 3.3: Independent PSU banks in 2019

\begin{tabular}{|c|c|}
\hline S.No & Bank \\
\hline 1 & Indian Overseas Bank(IOB) \\
\hline 2 & UCO bank \\
\hline 3 & Bank of Maharashtra \\
\hline 4 & Punjab and Sind Bank \\
\hline 5 & Bank of India \\
\hline 6 & Central Bank of India \\
\hline \hline
\end{tabular}

Source: https://affairscloud.com

Table: 3.4 Rank of banks after the above amalgamation

\begin{tabular}{|c|c|}
\hline Rank & Bank \\
\hline 1 & State Bank of India \\
\hline 2 & Punjab National Bank \\
\hline 3 & Bank of Baroda \\
\hline 4 & Canara Bank \\
\hline 5 & Union Bank of India \\
\hline \hline 6 & Indian Bank \\
\hline \hline 7 & Central Bank of India \\
\hline \hline 9 & Indian Overseas Bank \\
\hline \hline 10 & UCO bank \\
\hline \hline 11 & Bank of Maharashtra \\
\hline \hline 12 & Punjab and Sind Bank \\
\hline \hline
\end{tabular}

Source: $\underline{\text { https://affairscloud.com }}$ 
Top three amalgamated banks in ranking are Indian Overseas bank, UCO bank and Bank of Baroda which are all public sector banks.

\section{IV.REASONS FOR MERGER}

* To strengthen the growth of economic consolidation is anticipate to generate hardly, and durable borrowers.

* To rescue and re-energize the Indian banking sector

* The in advance capital of Rs 55,250 crore could be charged into the PSBs.

* Advances and Deposits of 2/3 generate a path to India's gross domestic product of $\$ 5$ trillion.

* Intended to assist the growth of India's economy.

* The operational performance benefits that decrease the price of borrowing.

\section{RESULTS}

Table 3.5: Detail of $M \& A$ 'S Deals for the year 2015 and 2016 in Terms of Value and Volume

\begin{tabular}{|c|c|c|c|c|}
\hline \multicolumn{3}{|c|}{2015} & \multicolumn{2}{|c|}{2016} \\
\hline & Count & $\begin{array}{l}\text { Value } \\
\text { (USS } \\
\text { million) }\end{array}$ & Count & $\begin{array}{l}\text { Value } \\
\text { (USS } \\
\text { million) }\end{array}$ \\
\hline Domestic & 483 & 16,360 & 505 & 25,141 \\
\hline Inbound & 258 & 9,948 & 204 & 21,396 \\
\hline $\begin{array}{c}\text { Outboun } \\
d\end{array}$ & 146 & 3,708 & 158 & 9,650 \\
\hline Total & 887 & 30,0107 & 867 & 56,187 \\
\hline
\end{tabular}

Even though on the volume front the year 2016 saw a marginal decline of $2 \%$ with 867 deals compared to 887 deals in 2015.However, the volume witnessed an increase when compared to 2014 I. e. 794 deals and 2013 i.e. 762 deals (Figure 1\&2).The average deal size for 2016 amounted to US\$ 161 million in 2015.This became the highest ever average deal value on record in the Indian M\&A market. The year, even saw domestic deals worth US\$ 25.1 billion, the highest yearly value on record. An increase of 5\% was noticed against 2015 on the volume front in the domestic deals (Table 1). The value of M\&A in 2016 was the highest in 6 years, on the volume front there was a slight decline from the past year but the deals worth were still more. The key trend noted in 2016 was the large companies from the cement sector and power sector indulging in M\&A activities to reduce their debts.

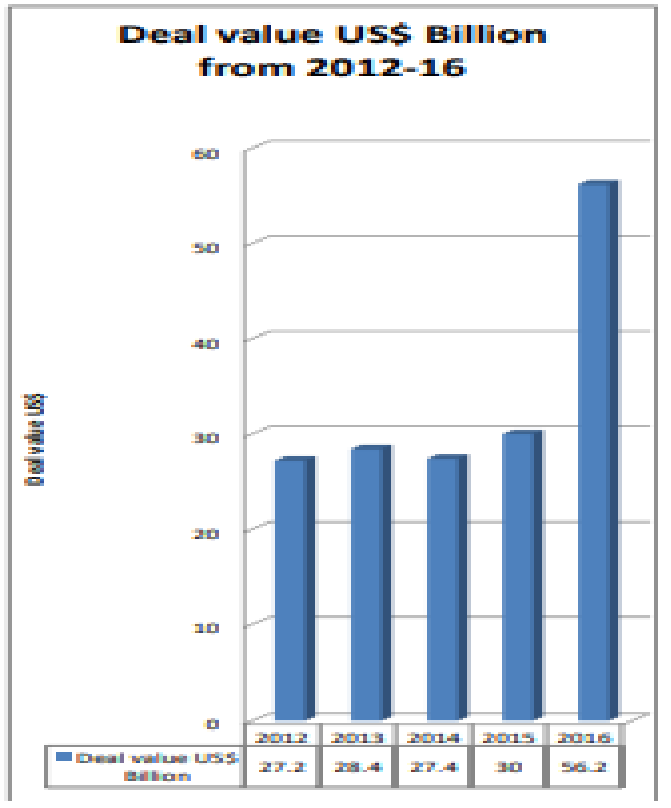

Graph: M\&A activities (Deal value US\$) of the Indian Companies

No. of Deals from 201216

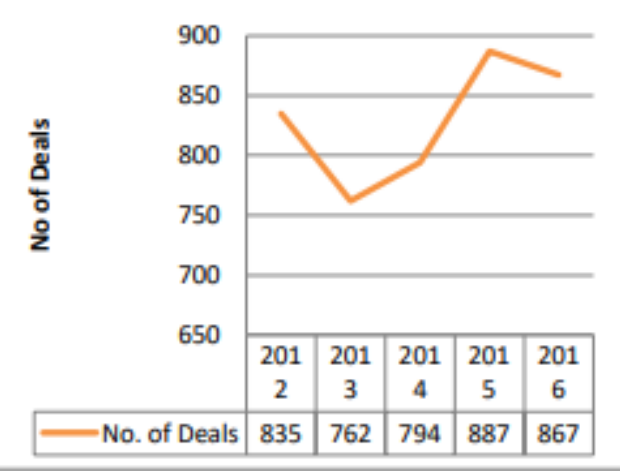

Graph: M\&A activities (Number of deals) of the Indian

\section{Companies}

The rise in cross-border can be attributed to the inbound deals which increased from US\$ 9.9 billion to US\$ 21.4 billion. And with a better FDI policy and relaxations given under the policy have definitely benefited and with foreign investors showing interest in investing in India, cross border activities are expected to rise. This could be attributed as one of the reasons of the increase in the domestic M\&A activities. FDI inflows have also increased, with the US being the highest contributor of FDI inflows of US \$38.5 billion.

Consolidation was also the theme for 2017 with one major deal of Vodafone and Idea merger coming through which is estimated to be a US \$ 27 billion transaction which has taken the telecom industry by storm and will make the largest telecom company in India and this mega merger was the sole reason for the increase in the deal activities in the first half of the 2017 denoting $80 \%$ of the total value of deals. 
The reason cited for this mega merger is the coming of Reliance Jio in the market and the extreme popularity with its attractive offers that it is getting from the customers and also to consolidate its position in the market by coming together to operate in the same field as that of Airtel and Jio which use superior data services.2017 M\&A activities were driven solely by the mega deals like Vodafone-Idea merger.

Table 3.6: Details of M\&A activities sector-wise for the

\begin{tabular}{|c|c|c|} 
KEY SECTORS & & \\
\hline $\begin{array}{c}\text { NOTABLE } \\
\text { SECTORS }\end{array}$ & VOLUME & USS \\
\hline Cement & 17 & 5,239 \\
\hline Financial services & 91 & 7,297 \\
\hline Infrastructure & 92 & 4,041 \\
\hline Oil and gas & 18 & 19,615 \\
\hline Pharmaceuticals & 51 & 4,557 \\
\hline Retail and consumer & 80 & 635 \\
\hline Telecom & 19 & 2,424 \\
\hline Technology & 106 & 2,083 \\
\hline
\end{tabular}

Table 3.7: Details of the M\&A activities for the 1st quarter of 2017 in key sectors

\begin{tabular}{|c|c|c|}
\hline \multicolumn{2}{|c|}{ Key Sectors for the lst quarter of year 2017 } \\
\hline \multicolumn{2}{|c|}{ Notable Sectors } \\
\hline Start-up & 23 & 363 \\
\hline Technology & 21 & 459 \\
\hline Manufacturing & 11 & 453 \\
\hline Pharmaceutical & 10 & 382 \\
\hline Retail \& Consumer & 7 & 108 \\
\hline Telecom & 3 & 27,479 \\
\hline
\end{tabular}

\begin{tabular}{|c|c|c|c|c|}
\hline + Oriental & $\mathrm{k}$ of $\mathrm{C}$ & me & + United Bank & $x$ 이 0 \\
\hline & PNB & $O B C$ & United Bank of India & Amalgamated bank \\
\hline Total business (n cure ef) & $11,82,224$ & $4,04,194$ & $2,08,106$ & $17,94,526$ \\
\hline Gross advances (ncove e) & $5,06,194$ & $1,71,549$ & 73,123 & $7,50,867$ \\
\hline Deposits (in coree ?) & $6,76,030$ & $2,32,645$ & $1,34,983$ & $10,43,659$ \\
\hline CASA ratio & $42.16 \%$ & $29.40 \%$ & $51.45 \%$ & $40.52 \%$ \\
\hline Domestic branches & 6,992 & 2,390 & 2,055 & 11,437 \\
\hline PCR & $61.72 \%$ & $56.53 \%$ & $51.17 \%$ & $59.59 \%$ \\
\hline CETIratio & $6.21 \%$ & $9.86 \%$ & $10.14 \%$ & $7.46 \%$ \\
\hline CRAR ratio & $9.73 \%$ & $1273 \%$ & $13.00 \%$ & $10.77 \%$ \\
\hline Net NPA ratio & $6.55 \%$ & $5.93 \%$ & $8.67 \%$ & $6.61 \%$ \\
\hline Employees & 65,116 & 21,729 & 13,804 & $1,00,649$ \\
\hline & & & & Heasummate \\
\hline
\end{tabular}

.Source - The Economic Times

\section{CONCLUSION}

Indian Banking industry is one among the quickest creating areas in the developing economies which had transformed into a proficient apparatus to encourage the advancement of the Indian economy. Initially banks were converged to spare non-performing banks or non productive banks yet as time built up the framework excessively progressed. In the ongoing occasions mergers and acquisitions is the most worthwhile instrument for the development of the Indian economy as far as grounds of business development, benefit and hierarchical rebuild and furthermore give confirms as a helpful apparatus for endurance of powerless banks by converging into bigger bank. India has gotten the most looked for after goal for M\&A bargains. Despite the fact that our economy is still in the newborn child arrange yet at the same time this economy is sufficiently enormous to give chances to remote speculations. Indian economy has even held its ground and not vacillated in the midst of the notable worldwide changes as Brexit and the presidential races in the United States of America and local changes as administrative systems, with by and large 2016 being a fascinating year for M\&A exercises in India.

Findings :

From Table No - 2.1 it is observed that Reserve Bank of India (RBI) in its latest annual report of 2019 has indicated that the rate of growth of frauds maybe not substantial but the amount involved in frauds has gone up by a whopping 73.8 per cent which has weakened the Indian economy. The Government has taken efforts towards speedy detection and accountability where the number of fraud cases reported in 2018-19 by banks increased by 15 per cent compared to last year. The RBI report states that among bank groups, PSBs or public sector banks which constitute the largest market share in bank lending have accounted for the bulk of frauds reported in 2018-19 which was followed by private sector banks and foreign banks.

The merger and acquisition has a greater impact on bank crisis which has scaled up banks quickly, its efficiency has been enhanced, has enabled businesses to fill the gap of technology and money loss and builds a strong team of employees.

Examples of PNB and Canara Bank merging has shown that NPA value has decreased which indicates that mergers have a greater impact on bank crisis and management.

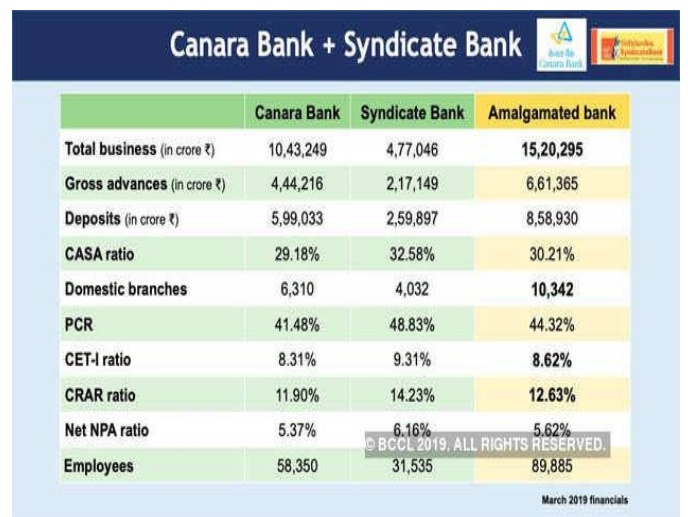

\section{Source - The Economic Times}

From the above two tables we infer that the combined effect of bank mergers has led to increase in number of employees and also the deposit which is a positive aspect of merger 


\section{REFERENCES}

1. T.Sanjeev Kumar, Mergers And Acquisitons In India, Anveshana's International Journal Of Research In Regional Studies, Law, Social Sciences, Journalism And Management Practices, Volume 1, Issue 10 (2016, Nov) (Issn-2455-6602) Online

2. Ms. Ramya Sree. M, Relevance Of Indian Mergers \& Acquisitons To Fdi, Veshana's International Journal Of Research In Regional Studies, Law, Social Sciences, Journalism And Management Practices, Volume 1, Issue 8 (2016, Sept) (Issn-2455-6602) Online

3. An article titled "Is Merger of Societies an Ultimate Solution ? ( A Postmortem Analysis of PACS in Viziangaram District - A..P.), Published in the Journal Indian Co- operative Review, New Delhi, New Delhi, October, 2005.

4. //economictimes.indiatimes.com/articleshow/67342863.cms?from=md r\&utm_source=contentofinterest\&utm_medium=text\&utm_campaign= cppst

5. https://www.business-standard.com

6. https://www.thehindubusinessline.com

7. https://affairscloud.com > list-mergers-acquisitions-bank-india

8. https://www.moneycontrol.com/news/business/mergers-acquisitions/di gging-deeper-the-big-bank-merger-what-why-and-what-next-4411711. $\underline{\mathrm{html}}$

9. www.rbi.org

\section{AUTHORS PROFILE}

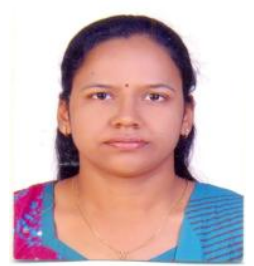

Ms. SMRITI NAGARIA, MBA (FINANCE) APSET,(Ph.D) Teaching Experience - 8 Years Study Details ICSE and ISC - Nasr School, Hyderabad B.Com (Regular) - St Francis College for Women, Begumpet, Secunderabad

MBA (Finance) - Stanley College of Engineering \& Technology for Women, Abids, Hyderabad

Passed all examinations in First Division

Ph.D - Pursuing from Osmania University, Hyderabad

E-Mail Id: smrnags19@gmail.com

Contact No : 9493387140

Ms.Smriti Nagaria, is an Assistant Professor in the Department of Business Management, St.Joseph's Degree \& PG College,Hyderabad since 2013. Prior to this she worked at Bharat PG College for Women ,Kachiguda, Hyderabad for 1 Year 6 Months. Specialized in Finance she teaches finance related subjects for both BBA and MBA courses. She has a keen interest in learning more and updating her knowledge periodically. She has contributed to the college in various activities. She has 20 papers to her credit which are published in International Journals ,International and National Conference/Seminars and another 7 papers are under publication for which confirmation is received.

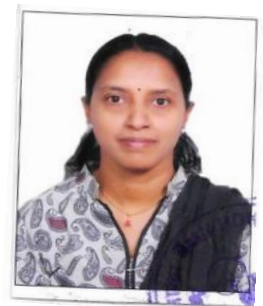

\section{Dr.R.Lavanya Kumari}

M.Com,MBA(Finance),M.Phil, Ph.D

Teaching Experience : 19 Years

Email: lavanyakumarir@gmail.com

Contact No :9912481383

Dr.R.Lavanya Kumari, is a doctorate from Karpagam University and is a lecturer in Loyola Academy ,Old Alwal. She is very dynamic ,has zeal to learn and update her knowledge. She has 54 articles to her credit which has been published in National , International Journal/seminar /Conference proceedings .

\section{PROFESSIONAL ACHIEVEMENTS}

- Guest Faculty - School of Informatics Technology, JNTUH, Hyderabad

- Part of Review Board member for Global Journal for Educational and Research (peer reviewed journal)

- Worked as a Guest faculty for various study centers (Punjab University, Periyar University and Pondicherry University) at Hyderabad

- Worked as a visiting faculty for Stanford P.G. College \& Vasavi College of Engineering. 